\title{
Evaluasi Penyelenggaraan Diklat Jarak Jauh (DJJ) pada Balai Diklat Keagamaan Medan
}

\author{
Ahmaddudin
}

Drs. Ahmad Dudin adalah peneliti Puslitbang Pendidikan Agama dan

Keagamaan - Badan

Litbang dan Diklat Kementerian Agama RI

Naskah diterima 15 September 2011. Revisi pertama, 30 September 2011, revisi kedua, 15 Oktober 2011 dan revisi terakhir 25 Nopember

\section{Abstact}

Improved Human Resources of the Ministry Of Religious Affairs is inevitable. All this time it has been implemented conventionally through a series of training programs carried out in various Training Centers distributed in as many as 12 regions of the country. However, such a program pattern has scarcely reached its entire human resources nationwide. The number of training instructors as the main benefactors is also limited. One effective way to solve that problem will be through a Distant Training (PJJ). Since 2009, MORA Training Centers in Medan have started it. As regards its effectiveness in achieving its results, this paper will pinpoint the results found from the evaluation of the distance education and training implementation in MORA Training Centers of Medan. 
Keywords: Evaluation, Implementation, Distant Training

\section{Abstrak}

Peningkatan SDM pegawai Kementerian agama merupakan keniscayaan. Selama ini peningkatan SDM itu telah dilakukan secara konvensional melalui diklat di kampus Pusdiklat dan kampus-kampus Balai Diklat yang tersebar pada 12 wilayah di Indonesia. Namun pola diklat itu belum menjangkau seluruh SDM kementerian agama yang tersebar luas di Indonesia. Jumlah widyaiswara sebagai pengampu mata diklat juga terbatas. Salah satu cara yang efektif untuk mengatasi permasalahan itu melalui Pendidikan Jarak Jauh (PJJ). Sejak tahun 2009, Pusdiklat dan Balai-balai diklat di daerah telah menyelenggarakan diklat jarak jauh. Bagaimana efektivitas pencapaian hasil diklat jarak jauh tersebut. Tulisan ini memaparkan hasil evaluasi terhadap penyelenggaraan diklat jarak jauh di Balai Diklat Keagamaan Medan.

Kata Kunci: Evaluasi, Penyelenggaraan, Diklat Jarak Jauh

\section{PENDAhuluan}

Upaya meningkatkan kompetensi, pengetahuan dan keterampilan SDM pegawai kementerian agama seperti: tenaga kependidikan, tenaga keagamaan dan tenaga administrasi yang menangani urusan pembangunan bidang agama merupakan urusan yang sangat strategis. Tugas tersebut merupakan salah rumusan yang termuat dalam visi dan misi Badan Litbang dan Diklat Kementerian Agama RI, yakni terciptanya SDM kementerian agama yang berkualitas, serta lahirnya kebijakan kementerian agama RI berbasis riset. ${ }^{1}$

Selama ini tugas untuk meningkatkan kompetensi SDM telah dilakukan secara konvensional melalui diklat di kampus Pusdiklat dan kampus-kampus Balai Diklat yang tersebar pada 12 wilayah di Indonesia. Permasalahan yang dihadapai dalam pola diklat konvensional tersebut adalah sulitnya menjangkau seluruh SDM

${ }^{1}$ KMA Nomor 3 tahun 2006. 
kementerian agama dengan jumlah (kuantitas) yang besar dan tersebar luas di seluruh wilayah NKRI. Jumlah widyaiswara yang mengampu mata diklat pada seluruh balai diklat dan pusat diklat kementerian agama berjumlah 346 orang. Jumlah guru Madrasah, Pondok Pesantren, dan GPAI yang berstatus swasta dan negeri yang berhak mengikuti diklat berjumlah 1.041 .890 orang. ${ }^{2}$ Jumlah tersebut belum termasuk jumlah tenaga penyuluh, pembina siaran dan tamadun, penyelenggara haji, penghulu, pengelolah zakat dan wakaf, pembina kemasjidan dan takmir. Diperlukan biaya dan waktu yang panjang untuk mendiklat seluruh pegawai tersebut.

Melalui optimalisasi anggaran penyelenggaraan diklat baru dapat mencover sebagian dari tenaga SDM Kementerian Agama. Dari segi siklus tahunan diklat baru mencapai 7 tahunan. Artinya seseorang baru dapat mengikuti diklat setelah tujuh tahun berikutnya, dengan asumsi pembagian jatah dan jadwal dilakukan secara adil. Idealnya, setiap pegawai dapat memperoleh kesempatan untuk memperoleh diklat setiap dua hingga empat tahun, atau bahkan setiap saat ia membutuhkannya. ${ }^{3}$ Hal tersebut sangat mempengaruhi mutu dan kinerja layanan tugas-tugas yang diemban oleh Kementerian Agama. Oleh karena itu perlu dilakukan terobosan untuk mengatasi keterbatasan tersebut. Salah satu pendekatan yang dapat dipilih adalah diklat jarak jauh, dengan menggunakan teknologi informasi dan komunikasi (TIK). Pendekatan ini secara teoretis mampu menorobos batas-batas geografis, sehingga setiap orang memiliki kesempatan yang terbuka untuk mengakses materi diklat atau mengikuti diklat sesuai dengan minat, tugas dan fungsinya.

Pendidikan Jarak Jauh (PJJ) dapat digunakan sebagai salah satu cara yang efektif untuk mengatasi permasalahan pendidikan yang sulit diatasi dengan cara konvensional. Kepala Badan Litbang dan Diklat pada beberapa tahun terakhir menekankan tentang pentingnya penggunaan Diklat Jarak Jauh (DJJ) dan Diklat di

2 Data Statistik Keagamaan Tahun 2009, Kementerian Agama RI.

3 Position Paper Kepala Badan Litbang dan Diklat Kementerian Agama pada Rakernas Balitbang di Banjarmasin tahun 2008. 
Tempat Kerja (DDTK) sebagai teknik untuk meningkatkan akses terhadap pendidikan dan latihan serta untuk meningkatkan frekuensi alumni diklat. Menindaklanjuti hal tersebut, Pusdiklat dan balai diklat yakni: Balai Diklat Bandung, Balai Diklat Jakarta, Balai Diklat Surabaya, Balai Diklat Bali, Balai Diklat Medan, Balai Diklat Palembang, Balai Diklat Padang, Balai Diklat Manado, Balai Diklat Makasar, dan Bali Diklat Ambon dan Banjarmasin telah melakukan terobosan tersebut sejak tahun 2009.

Tujuan utama penyelenggaraan diklat jarak jauh pada Pusdiklat dan Balai diklat adalah untuk mempercepat siklus diklat dengan memanfaatkan penggunaan TIK dalam dunia kediklatan serta mengurangi keterbatasan jarak dan waktu antara penyelenggara diklat, tutor dan peserta diklat. Namun untuk mengetahui sejauh mana terobosan dan tujuan DJJ dapat terealisasi, dan bagaimana output yang dicapai merupakan sesuatu yang penting untuk diteliti dalam rangka memperbaiki dan meningkatkan efektivitas pencapaian hasilnya. Tulisan ini berupaya menemukan dan mengkaji fakta-fakta penyelenggaraan diklat jarak jauh yang telah diselenggarakan oleh Balai Diklat Kementerian Agama RI dengan mengambil kasus Balai Diklat Keagamaan Medan.

\section{KAJIAN TEORETIK}

\section{A. Konsep Evaluasi Program}

Dalam pelaksanaan evaluasi program terdapat bermacammacam model dan jenisnya. Hal tersebut tergantung pada tujuan evaluasi, sasaran, pendekatan, sumber data dan alokasi waktu yang tersedia. Robonson and Latchem mengemukakan; The nature of an evaluation varies according to its purpose, audience, approach, resources and time available. Dari aspek pendekatan, maka ada beberapa pendekatan dalam evaluasi program, yakni: goal oriented approach, the decision focused approach, the user oriented approach, responsive approach, goal free evaluation. ${ }^{4}$

${ }^{4}$ Farida Yusuf Tayibnapis. 2000. Evaluasi Program. Jakarta: Rineka Cipta, h. 25-35. 
Pendekatan Goal oriented approach, memakai tujuan program sebagai kriteria untuk menentukan keberhasilan. Evaluasi dengan pendekatan the decision focused approach dimaksudkan untuk membantu para pengelola program untuk membuat keputusan. Oleh karena itu rancangan evaluasi harus sesuai dengan kebutuhan untuk pengambilan keputusan. Evaluasi dengan pendekatan the user oriented approach dimaksudkan untuk memenuhi kebutuhan para user atau sasaran dari kebijakan atau program yang dilakukan. Elemen yang paling penting dalam pendekatan ini adalah keterlibatan pemakai yang paling potensial selama proses evaluasi berlangsung. Evaluasi dengan pendekatan responsive approach adalah berusaha untuk memahami program yang sedang dievaluasi dari berbagai sudut pandang. Evaluasi atau goal free evaluation yakni evaluasi yang tidak direncanakan untuk memenuhi tujuan tertentu, alasannya karena tujuan biasanya hanyalah sebuah formalitas dan jarang yang menunjukkan tujuan yang sebenarnya.

Hal yang menarik untuk dijelaskan adalah tentang evaluasi program adalah evaluasi yang bersifat formatif dan sumatif. Menurut Scriven, evaluasi formatif dapat dilaksanakan selama program berjalan untuk memberikan informasi yang berguna bagi pemimpin program untuk perbaikan program selanjutnya. Oleh karena itu setiap langkah Evaluasi formatif akan menghasilkan umpan balik yang segera kepada pemegang program, untuk digunakan sebagai dasar revisi program. Sementara Evaluasi sumatif dilaksanakan pada akhir program untuk memberikan informasi kepada pengambail keputusan tentang manfaat 'sebuah program. Evaluasi sumatif mengarah kepada keputusan kelanjutan sebuah program, berhenti atau dilanjutkan. ${ }^{5}$

Perbedaan antara kedua bentuk evaluasi program tersebut (formatif dan sumatif) dapat ditampilkan melalui tabel berikut: 6

\footnotetext{
${ }^{5}$ Ibid., h. 35-37.

${ }^{6}$ Farida Yusuf Tayibnapis. Op. Cit., h. 157-158.
} 


\begin{tabular}{|l|l|l|}
\hline \multicolumn{1}{|c|}{ Aspek } & \multicolumn{1}{|c|}{ Formatif } & \multicolumn{1}{c|}{ Sumatif } \\
\hline Tujuan & $\begin{array}{l}\text { - Merupakan hasil evaluasi } \\
\text { selama program sedang } \\
\text { berjalan. } \\
\text { - Untuk perbaikan program }\end{array}$ & $\begin{array}{l}\text { - Merupakan hasil dari } \\
\text { implementasi program pada akhir } \\
\text { atau periode tertentu } \\
\text { - Menerangkan pekerjaan yang } \\
\text { telah selesai }\end{array}$ \\
\hline Sifat & Informal & Formal \\
\hline Bentuk & $\begin{array}{l}\text { Dapat tertulis, audio visual, } \\
\text { lisan }\end{array}$ & Hampir selalu tertulis \\
\hline $\begin{array}{l}\text { Spesifika } \\
\text { si }\end{array}$ & $\begin{array}{l}\text { Tinggi difokuskan pada } \\
\text { kegiatan khusus atau materi } \\
\text { khusus yang dipakai oleh } \\
\text { orang tertentu dan tempat } \\
\text { tertentu }\end{array}$ & $\begin{array}{l}\text { Lebih moderat, dan lebih } \\
\text { berusaha mencatat ciri-ciri umum } \\
\text { program dalam berbagai segi, } \\
\text { sehingga kesimpulan dan } \\
\text { keputusan dapat diambil } \\
\text { berdasarkan laporan evaluasi } \\
\text { tersebut }\end{array}$ \\
\hline
\end{tabular}

Meskipun terdapat berbagai model dan pendekatan dalam melakukan evaluasi program, secara umum tujuan dari seluruh model dan pendekatan tersebut adalah untuk mengetahui efektivitas dari suatu program atau tindakan yang dilakukan. Dan dalam konteks pendidikan, evaluasi program dilakukan dalam rangka untuk mengetahui efektivitas penggunaan sumber daya (materials), efektivitas metode mengajar (teaching methods) dan banyak hal terkait lainnya, yang pada akhirnya dapat menyediakan informasi dan data untuk memperbaiki program.

\section{B. Pendidikan Jarak Jauh}

Istilah pendidikan jarak jauh (distance education) telah lama dikenal, yaitu sejak sekitar tahun 1870-an. Sistem pendidikan jarak jauh pada mulanya berbentuk pendidikan korespondensi dengan sasaran orang dewasa, dilakukan dengan menggunakan bahan belajar cetak atau tertulis, dan didistribusikan (delivery) melalui jasa pos. Dalam perkembangannya, penyelenggaraan pendidikan jarak jauh bukan hanya menggunakan bahan cetak saja, melainkan juga telah memanfaatkan berbagai media lain, termasuk media elektronik seperti program radio dan televisi, dan pada tahun 1990 telah menggunakan multimedia. Seiring dengan pesatnya kemajuan media non-cetak, maka makna pendidikan 
jarak jauh pun mengalami perkembangan. ${ }^{7}$ Secara singkat dapat dikatakan bahwa evolusi tersebut telah berkembang mulai dari pemanfaatan teknologi cetak pada awalnya, kemudian teknologi penyiaran dan rekaman sampai dengan teknologi internet. ${ }^{8}$

Saat ini terdapat berbagai istilah yang terkait dengan pendidikan jarak jauh yang digunakan secara bergantian dan dipandang sinonim oleh masyarakat, antara lain: pendidikan korespondensi (correspondence courses), belajar sendiri (selflearning), belajar mandiri (independent learning), belajar luwes (flexible learning), belajar privat terarah (directed private study), pendidikan alternatif (alternative education), pendidikan jarak jauh (distance education), belajar jarak jauh (distance learning), pendidikan terbuka (open learning), pendidikan terbuka dan jarak jauh (open and distance learning), kampus virtual (virtual campus), universitas tanpa gedung (university without classrooms or wallness education), belajar melalui internet (internet-based learning), belajar melalui jaringan (online learning), dan belajar melalui media elektronik (electronic learning atau e-learning). ${ }^{9}$

David Kember juga mengemukakan hal yang serupa bahwa selain pendidikan jarak jauh (distance learning), beberapa model dan istilah yang serupa dengan pendidikan jarak jauh adalah pendidikan terbuka (open learning), pembelajaran fleksibel (fleksibel learning), pembelajaran elektronik (eLearning). ${ }^{10}$

Tipe pendidikan jarak jauh menurut Blended atau Hybrida synchronous dimana terdapat bentuk pembelajaran di suatu tempat yang mempertemukan pengajar dan pembelajar secara

${ }^{7}$ Nurdin Ibrahim. 2005. "ICT Untuk Pendidikan Terbuka Jarak Jauh" dalam JURNAL TEKNODIK No. 16/IX/TEKNODIK/JUNI, h. 5.

${ }^{8}$ Sudirman Siahaan. 2005. "Pemanfaatan Teknologi dalam Penyelenggaraan Pendidikan Terbuka/Jarak Jauh," dalam JURNAL TEKNODIK No. 16/IX/TEKNODIK/JUNI, h. 20.

${ }^{9}$ Ibid., h. 21.

${ }^{10}$ David Kember. 2007. Reconsidering Open and Distance Learning in the Developing World. London: Routledge, h. 4-8. 
fisik, serta ditopang oleh penggunaan media dan teknologi informasi dan komunikasi yang lengkap dalam prosees pembelajaran seperti video konferensi dan chating.

\section{Penyelenggaraan DJJ}

Bentuk Pembelajaran Diklat Jarak Jauh (DJJ) yang diselenggarakan Pusdiklat Tenaga Teknis Keagamaan dan Balai Diklat Kementerian Agama RI, meliputi: pembelajaran berbasis modul tertulis dan pembelajaran berbasis TIK.11 Secara operasional, Pusdiklat Tenaga Teknis Keagamaan merumuskan pengertian Diklat Jarak Jauh (DJJ) adalah pertemuan antara tutor dan peserta diklat secara online internet.

Tujuan penyelenggaraan Diklat Jarak Jauh adalah untuk mempercepat siklus diklat, mengurangi keterbatasan jarak dan waktu antara penyelenggara diklat, tutor dan peserta diklat. Dengan Diklat Jarak Jauh penyelenggara, tutor dan peserta bisa saling berinteraksi kapan pun dan di mana pun. Dengan sistem ini, peserta dapat mengikuti diklat tanpa harus meninggalkan tugas. Di samping itu peserta dapat mengatur sendiri kecepatan belajarnya. Diharapkan dengan sistem ini baik penyelenggara, tutor dan peserta tidak ada lagi kendala dengan waktu belajar. ${ }^{12}$

Secara detail manfaat yang dapat diperoleh dari penyelenggaraan Diklat Jarak Jauh adalah: mengatasi masalah keterbatasan waktu pertemuan antara tutor dan peserta; tutor dapat meng-upload materi kapan saja dan di mana saja; tutor dapat meng-upload soal-soal latihan kapan saja dan di mana saja; tutor dapat melihat semua aktivitas peserta diklatnya kapan saja dan di mana saja; tutor dapat memberikan bimbingan ke peserta diklat secara langsung dengan fasilitas chatting atau forum; peserta diklat dapat mendaftar diklat kapan saja dan di mana saja; peserta diklat dapat mendownload materi diklat kapan saja dan di

${ }^{11}$ Kementerian Agama RI. 2008. Petunjuk Pelaksanaan Penyelenggaraan Diklat Jarak Jauh (Dji) Bagi Pegawai Tenaga Teknis Keagamaan, Jakarta: Pusdiklat Tenaga Teknis Keagamaan, h. 5.

${ }^{12}$ Ibid. 
mana saja; peserta diklat dapat berkonsultasi dengan tutor secara langsung dengan fasilitas chatting atau forum; peserta dapat mengerjakan soal-soal latihan kapan saja dan di mana saja; peserta dapat mengerjakan soal-soal ujian di mana saja dan kapan saja, dengan mengikuti diklat online secara tidak langsung; serta peserta diklat dapat meningkatkan kemempuannya dalam bidang TIK. ${ }^{13}$

Sebagai penyelenggara DJJ, Balai Diklat Keagamaan Medan memiliki tugas dan tanggung jawab sebagai berikut: menjaring peserta dengan memberitahukan ke masing-masing unit kerja calon peserta diklat adanya kelas baru; orientasi peserta; menyediakan bahan belajar cetak; mengembangkan bahan belajar penunjang; mengelola tempat kegiatan belajar; mengelola proses pembelajaran; memberikan bantuan belajar; melakukan penilaian hasil belajar; dan ujian akhir.

Administrator Balai Diklat Keagamaan untuk sistem Diklat Jarak Jauh bertugas dan bertanggungjawab; membuatkan account calon peserta diklat sesuai Balai Diklat Keagamaan masingmasing; mendaftarkan (enrollment) calon peserta ke mata diklat yang diinginkan; menunjuk seorang tutor untuk mengelola mata diklat sesuai kompetensi tutor; memantau perkembangan seluruh mata diklat dalam Balai Diklat Keagamaan yang dikelolanya; membuat laporan tentang hasil yang telah dicapai untuk tiap-tiap mata diklat secara lengkap (statistic); membantu atau mendampingi seorang tutor jika mengalami kesulitan ketika membuat materi diklat maupun mengupload file; berperan sebagai tutor jika terdapat tutor yang sedang menjalankan tugas lain maupun berhalangan.

Tutor sebagai pengampu mata diklat bertugas dan bertanggung jawab; menyiapkan materi mata diklat; menyiapkan materi presentasi; menyiapkan soal-soal latihan; menyiapkan soal-soal ujian; menyiapkan penugasan kepada peserta diklat; berinteraksi dengan peserta diklat; memberikan penilaian terhadap peserta diklat.

\footnotetext{
${ }^{13}$ lbid., h. $6-7$.
} 
Peserta DJJ adalah guru tingkat MTs, yang mempunyai tugas dan tanggung jawab sebagai berikut; mendaftar via email ke Balai Diklat Keagamaan yang akan diikuti; memilih mata diklat yang akan diikuti; mengikuti orientasi penjelasan diklat; mendapatkan account untuk akses ke http://djj.pusdiklatteknis.depag.go.id/; membaca kontrak pembelajaran dan memenuhinya sesuai dengan isi kontrak; mengikuti kelas pada http://djj.pusdiklatteknis.depag. go.id/; mengikuti tutorial baik online, tatap muka, maupun melalui siaran TV Edukasi; mengikuti ujian online sebagai syarat ujian akhir; mengikuti ujian akhir secara off line.

Organisasi penyelenggaranya DIJ terdiri atas: penanggung jawab umum, penanggung jawab operasional dan pelaksana yang terdiri atas: bidang akademis, bidang modul dan media lain, bidang kepesertaan, bidang tutorial dan evaluasi, bidang administrasi dan pelaporan, bidang keuangan.

\section{METODOLOGI PENELITIAN}

Penelitian ini adalah penelitian evaluasi program model Conteks Input Proses dan Produc (CIPP) terhadap program DJJ yang diselenggarakan oleh Balai Diklat Keagamaan Medan. Penelitian dilaksanakan pada bulan April hingga Juni 2011. Lokasi penelitian di Balai Diklat Keagamaan Medan.

Sumber data penelitian terdiri atas Kepala Balai Diklat Keagamaan (Thaha Daulay), Kepala Subag Tata Usaha (Sony Siregar), Kepala Subag Teknis sebagai ketua panitia penyelenggara (Parjuang Harahap), panitia penyelenggara (4 orang), Tutor (2 orang), administrator ( 2 orang), dan alumni DJJ (10 orang).

Pengumpulan data digunakan dengan bantuan instrumen angket, pedoman wawancara, lembar isian, pedoman observasi, dan lembar periksa kelengkapan dokumen.

Sesuai instrumen tersebut di atas, maka teknik yang digunakan dalam pengumpulan data adalah: wawancara, penyebaran angket, dan pemeriksaan kelengkapan dokumen. Juga dilakukan observasi terhadap perangkat keras dan tools yang digunakan dalam penyelenggaraan diklat jarak jauh. Studi 
dokumen dilakukan untuk memperoleh data tentang konteks, input, proses dan output DJJ.

Analisis data penelitian menggunakan teknik CIPP. Dimana secara umum akan ditampilkan gambaran kontekstual penyelenggaraan diklat (conteks), berbagai sumber masukkan penyelenggaraan diklat jarak jauh (input), proses penyelenggaraan diklat (process), serta output atau produk yang dicapai oleh diklat jarak jauh (product). Selain itu, analisa data juga akan menganalisis cost effectivenes atau unit-cost penyelenggaraan diklat jarak jauh, sehingga dapat diketahui perbandingan biaya diklat konvensional dan diklat jarak jauh.

\section{HASIL PENELITIAN DAN PEMBAHASAN}

\section{A. Konteks Penyelenggaraan DJJ}

\section{Perspektif Penyelenggaraan DIJ}

Program DIJ Provinsi Sumatera Utara dimulai sajak tahun 2010 hingga sekarang, dengan didasarkan kepada Surat Keputusan Badan Litbang dan Diklat Kementerian Agama No. BD/53/2008 tentang Pedoman Jarak Jauh dan No. BD/55/2009 tentang Desain Program Diklat Jarak Jauh Bagi Guru Mata Pelajaran Matematika MTs dan Bahasa Inggris MTs.

Secara umum, Program DJJ diarahkan untuk: (1) meningkatkan pengetahuan, keterampilan dan sikap mental/kepribadian guru sehingga mereka lebih professional dalam melaksanakan tugas kependidikan dan pembelajaran, (2) meningkatkan integritas dan moralitas, serta memantapkan semangat pengabdian dalam menjalankan tugas profesi sebagai guru. Sedangkan secara khusus, untuk mempercepat siklus diklat mengingat besarnya jumlah peserta diklat, lokasi dan pembiayaan.

Kegiatan pembelajaran DIJ pada BDK Medan dilakukan secara on-line sejak bulan Juni s/d September 2010. Pembelajaran secara on-line dilakukan melalui penggunaan internet, baik melalui WEB, chatting, forum, email, facebooks, dan lain-lain. Nama situsnya http://dji.pusdiklat teknis.depag.go.id/. Kegiatan pembelajaran DJJ secara off-line dilakukan pada awal Juni (pembukaan DJI), pertengahan DIJ (dua bulan pelaksanaan), dan akhir DIJ. Adapun 
pelaksanaan pembelajaran secara off-line dilakukan di kelas, terutama untuk mendiskusikan persoalan DIJ yang krusial termasuk dalam rangka melakukan pre-test dan post-test.

\section{Urgensi Penyelenggaraan DJJ}

Diklat Jarak Jauh merupakan salah satu sistem di dalam kegiatan pembelajaran berbasis TIK. Urgensi dilaksanakannya DJJ adalah untuk mempercepat siklus diklat, mempergunakan TIK dalam dunia kediklatan serta mengurangi keterbatasan jarak dan waktu antara penyelenggara diklat, tutor dan peserta diklat. Dengan Diklat Jarak Jauh penyelenggara, tutor dan peserta bisa saling berinteraksi kapan pun dan di mana pun. Dengan sistem ini, peserta dapat mengikuti diklat tanpa harus meninggalkan tugas. Disamping itu peserta dapat mengatur sendiri ketuntasan belajarnya dan peserta dapat mengatur sendiri aktivitasnya. Namun demikian, tidak berarti DJJ sama sekali tidak melakukan tatap muka. Melainkan tatap muka dilakukan pada awal, pertengahan dan akhir program.

Beberapa alasan formal dan faktual, bahwa urgensi penyelenggaraan DJJ dari segi kebutuhan pemakai DJJ di BDK Medan adalah karena: (1) Banyaknya Pegawai Kemenag yang belum mengikuti diklat (Medan - Aceh +25.000 orang pegawai); dan (2) Siklus diklat \pm 5 tahun dengan DJJ dapat disingkat menjadi \pm 2 tahun. Adapun sebelum penyelenggaraan DJJ penting juga diperhatikan adanya diklat pendahuluan atau orientasi bagi calon peserta DJJ terkait penguasaan IT/web/internet, agar dalam pelaksanaan DJJ nantinya tidak banyak menemui kendala. ${ }^{14}$

\section{B. Input Penyelengaraan DJJ}

1. SDM Pelaksana DJJ

\section{a. Tutor}

Tutor adalah widyaiswara atau fasilitator yang membidangi subtansi atau materi mata diklat dan bertanggungjawab terhadap

14 Wawancara dengan Tutor DJJ pada BDK Medan, Drs. Lutfi Maulana NST, M. Pd, Juni 2011 
pembimbingan kepada peserta DJJ melalui koresponden virtual (internet atau website). Jumlah tutor DJJ BDK Medan adalah 2 orang yaitu: Tutor DJJ untuk bidang studi matematika diampu oleh Drs. Lutfi Maulana NST, M. Pd, dan tutor DJJ untuk bidang studi Bahasa Inggris yang diampu oleh Drs. Abdussalam, M. Pd.

Dari segi kualifikasi akademis, Drs. Lutfi Maulana NST, M. Pd yang membidangi program DJJ matematika adalah Sarjana Pendidikan Jurusan Matematika dan meneruskan magisternya di bidang administrasi pendidikan. Ia telah mengikuti Diklat terkait penggunaan komputer dan internet, Diklat pembuatan media pembelajaran berbasis computer atau internet, Diklat pengelolaan jarak jauh, dan orientasi DJJ melalui TVE. Adapun Drs. Abdussalam, M. Pd, yang membidangi program DJJ Bahasa Inggris juga seorang sarjana pendidikan jurusan Bahasa Inggris. Program magisternya juga jurusan Bahasa Inggris, dan sekarang sedang mengikuti program Doktor bidang pendidikan. Beliau juga pernah mengikuti pendidikan di Australia terkait teaching of English to speaking of other languages pada ICTE The University of Queensland (UO). Diklat yang pernah diikuti antara lain Diklat guru Bahasa Inggris se-Indonesia, Diklat teknisi laboratorium Bahasa, dan Diklat teknisi komputer.

Dari segi kualifikasi akademik kedua tutor DJJ Medan telah memenuhi persyaratan menjadi tutor. Dilihat dari kemampuan operasional pendidikan terkait dengan DJJ bidang studi matematika dan bahasa Inggris, kedua tutor telah mampu mengoperasikan komputer, mampu menggunakan IT, dan dapat menggunakan media blog berbasis internet atau website, chatting, forum, email, facebooks, dan lain-lain. Di samping itu telah mengikuti diklat IT seperti diklat siaran televisi program pendidikan dan non IT berupa diklat penelitian pembelajaran dan Broadcasting Mute Menkominfo Jogjakarta. Dengan demikian dari persyaratan menjadi tutor, maka untuk kedua tutor DJJ Medan telah memenuhi syarat tingkat pendidikan sesuai dengan jurusan atau kompetensi, mereka telah ikut pelatihan IT dan juga dapat menjalankan tugas dan fungsinya dengan baik. Tugas dan fungsi tutor sesuai dengan juklak adalah: pertama, membuat mata diklat baru (topik baru) sesuai kompetensi masing-masing lengkap 
dengan halaman yang diperlukan diantaranya: abstraksi, sinopsis, modul utama, modul penunjang, sumber bacaan, dan lain-lain. Dalam hal ini tutor telah membuat modul penunjang dan memberi peluang kepada peserta DJJ untuk membaca referensi-referensi terkait yang diakses melaui internet; kedua,dapat mengelola kelas (off line) yang dilakukan pada awal, pertengahan dan akhir DJJ; ketiga, membuat bank soal, ini dilakukan sebagai bahan pre-test dan pos-test; keempat, memonitor perkembangan sistem belajar para peserta DJJ; Kelima, memberikan penilaian kepada kepada masing-masing peserta DJJ; keenam, membuat laporan per minggu atau per bulan tentang statistik peserta DJJ, ini yang belum sepenuhnya dilakukan; dan ketujuh, membuat laporan tentang peserta yang lulus ujian secara online untuk diusulkan mengikuti ujian offline.

Beberapa kendala yang dihadapi oleh tutor dalam pembelajaran DJJ adalah kurang sarana IT, kurang sarana internet (Band Witch kurang), kurang tenaga tutor, dan kurang honor karena kesibukan yang terlalu berat menangani berbagai persoalan yang dihadapi peserta DJJ, sehingga waktunya tersita. Kendala-kendala inilah yang menjadikan tutor kurang maksimal dalam melakukan pembimbingan kepada peserta DJJ dalam upaya meningkatkan pemahaman modul dan kompetensi peserta DJJ.

b. Administrator DJJ

Diantara penyelenggara kegiatan DJJ adalah tenaga administrasi (administrator). Administrator bertanggungjawab mengelola administrasi penyelenggaraan DJJ baik yang mencakup administrasi tutor atau widyaiswara, peserta maupun materi diklat termasuk jadwal permata diklat. Petugas administrator DJJ BDK Medan jumlahnya ada dua, yaitu Sri Rayani, S. Si dan Gunarno, S. Si. Kedua petugas administrasi adalah sarjana dan telah mengikuti diklat IT, mampu mengoperasikan komputer dan dapat menggunakan media blog berbasis web juga perangkat penunjang diklat DJJ lainnya. Dengan demikian mereka dianggap telah memenuhi syarat sebagai administrasi terkait kualifikasi akademis, kompetensi, dan pengalaman. Ada satu hal yang penting diperhatikan yaitu tidak hanya berlatar belakang pendidikan S.1 
saja tetapi juga dari sarjana IT, mampu berbahasa Inggris dan telah terlatih. ${ }^{15}$

Administrator sistem Diklat Jarak Jauh bertugas dan bertanggungjawab: (1) membuatkan account calon peserta diklat sesuai Balai Diklat Keagamaan masing-masing; (2) mendaftarkan (enrollment) calon peserta ke mata diklat yang diinginkan; (3) menunjuk seorang tutor untuk mengelola mata diklat sesuai kompetensi tutor; (4) memantau perkembangan seluruh mata diklat dalam Balai Diklat Keagamaan yang dikelolanya; (5) membuat laporan tentang hasil yang telah dicapai untuk tiap-tiap mata diklat secara lengkap (statistik); (6) membantu atau mendampingi seorang tutor jika mengalami kesulitan ketika membuat materi diklat maupun mengupload file; dan (7) berperan sebagai tutor jika terdapat tutor yang sedang menjalankan tugas lain maupun berhalangan.

Terkait dengan tugas administrator dalam penyelenggaraan DJJ Balai Diklat dan Keagamaan Medan yang telah dilakukan adalah; (1) melaporkan ke pusdiklat bahwa akan dibuka kelas DJJ; (2) mendaftarkan calon peserta dengan mengirim surat ke peserta yang akan diikutkan; (3) memproses rekrutmen peserta; (3) membantu peserta dan tutor dalam mengakses internet secara on Line dan off Line; (4) memberikan informasi kepada tutor dan peserta tentang hal-hal yang berhubungan dengan diklat DJJ.16

2. Peserta DJJ

Peserta DJJ BDK Medan adalah guru tingkat MTs jurusan Matematika dan Bahasa Inggris, yang mempunyai tugas dan tanggung jawab sebagai berikut: mendaftar via email ke balai diklat keagamaan yang akan diikuti, memilih mata diklat yang akan diikuti, mengikuti orientasi penjelasan diklat, mendapatkan account untuk akses ke http://djj.pusdiklatteknis. depag.go.id/a membaca kontrak pembelajaran dan memenuhinya sesuai dengan isi kontrak, mengikuti tutorial baik online, tatap muka, siaran TVE,

${ }^{15}$ Wawancara dengan Kepala Subag TU BDK Medan, Juni 2011

${ }^{16}$ Wawancara dengan petugas admin DJJ Medan, Sunaryo, S.Si, Juni 2011. 
ujian online sebagai syarat ujian akhir, dan mengikuti ujian akhir secara off line.

Seleksi administrasi terhadap calon peserta DJJ dilakukan oleh administrator dan diumumkan secara online melalui website. Persyaratan untuk rekruitmen peserta DJJ Terkait kompetensi, kualifikasi akademis, pengalaman, usia adalah; (a) sesuai dengan jurusan/materi yang diampu; (b) menguasai aktif di dunia internet; (c) usia maksimal \pm 50 tahun. Jumlah anggota perkelompok belajar Bahasa Inggris dan Matematika yang lulus seleksi masing masing berjumlah 20 orang. Setelah dinyatakan lulus seleksi sebagai anggota kelompok belajar DJJ, peserta wajib melakukan kegiatan belajar mandiri secara teratur di tempat masing-masing.

Hak peserta DJJ adalah mudah mengakses modul secara online, mendapatkan pembimbingan dengan baik dari para tutor, mendapatkan materi sesuai dengan kebutuhan, mendapatkan surat tanda lulus setelah menyelesaikan program DJJ. Sedangkan kewajibannya adalah peserta mengakses secara aktif sesuai dengan jadwal pelaksanaan per-mata diklat, menyelesaikan tugas, kuis dan ujian per-mata diklat, berkomunikasi aktif dengan tutor, mengikuti ujian akhir kelulusan diklat DJJ.

Permasalahannya adalah belum seluruh peserta DJJ menguasai dengan baik kegunaan IT dalam mengoperasikan Website (internet). Di samping itu juga belum seluruh sekolah telah terakses dengan wifi (jaringan internet), koneksi internet belum baik yang diakibatkan oleh pilihan koneksi internet yang dipakai belum baik dan lokasinya belum terjangkau secara sempurna oleh layanan jasa internet.

\section{Teknologi Informasi DJJ}

Sarana dan prasarana yang dipergunakan dalam DJJ adalah internet, TVE dan siaran radio. Sedangkan pembelajaran DJJ ofline menggunakan modul dalam CD. Sarana dan prasarana pembelajaran yang dimiliki Balai Diklat Keagamaan dapat dikatakan cukup memadai dengan pola diklat dan program kegiatan yang diselenggarakan. Sehingga proses pembelajaran dapat berlangsung secara baik, lancar, efektif, dan efisien. Ruang belajar telah 
dilengkapi dengan meja dan kursi untuk peserta dan instruktur. Pada masing-masing ruangan (ruang belajar maupun ruang diskusi) dilengkapi dengan papan tulis jenis white board, Sound System, sebagian terdapat overhead projector (OHP), dan sebagian telah ada LCD untuk presentasi, serta notebook.

Peralatan yang dipergunakan peserta DJJ adalah notebook, untuk peserta di pinggir kota dengan mengunkan modem yang mobile dengan layanan operator tertentu seperti GSM dan CDMA. Namun untuk peserta yang berlokasi diperkotaan umumnya menggunakan warnet atau koneksi jaringan internet di sekolah masin-masing. Persoalannya adalah untuk daerah tertentu yang jauh dari perkotaan sulit atau lambat dalam mengakses internet. Disamping itu perlu biaya tinggi untuk mengakses internet baik yang melalui modem maupun melalui warnet.

\section{Kurikulum DJJ}

Kurikulum DJJ disesuaikan dengan Kurikulum diklat reguler berdasarkan kursil (kurikulum dan silabus) Pusdiklat Tenaga Teknis Keagamaan, kemudian dijabarkan dalam materi bahan ajar baik berupa modul berbasis IT (internet atau website). Namun demikian, Balai Diklat Keagamaan diberi peluang/ kesempatan untuk mengembangkan materi diklat dengan cara mengupload materi yang sejenis melalui web sesuai kurikulum yang telah ditetapkan oleh Pusdiklat Tenaga Teknis Keagamaan. Pengembangan materi tersebut dapat didownload oleh peserta DJJ.

Materi DJJ berdasarkan kurikulum terdiri dari 1) materi kelompok dasar, 2) materi kelompok inti dan 3) materi kelompok penunjang. Materi kelompok dasar, merupakan mata diklat yang bersifat mendasar yang harus diketahui oleh seluruh peserta DJJ yang mencakup peraturan-peraturan, Undang-undang yang bersifat nasional dan berbagai kebijakan di lingkungan Kementerian Agama. Materi kelompok inti, mencakup mata diklat berkenaan dengan subtansi tugas tenaga teknis keagamaan bidang pendidikan berdasarkan jenis dan jenjang diklat, seperti: pengembangan KTSP, model pembelajaran, pemanfaatan media dan sumber pembelajaran, pendalaman materi, pengembangan diri maupun sistem penilaian pembelajaraan. Sedangkan materi 
kelompok penunjang berisikan materi yang dapat dipergunakan untuk memperkaya wawasan pemahaman pengetahuan peserta DJJ. Adapun bobot masing-masing materi kelompok diklat adalah $10 \%$ materi kelompok dasar, 80\% materi kelompok inti dan $10 \%$ materi kelompok penunjang. Dalam menunjang meteri diklat, Tutor mengupload materi sejenis ke dalam website yang dapat didownload oleh peserta DJJ dimana dan kapan saja. Namun demikian materi DJJ belum disesuaikan dengan kebutuhan riil masing-masing peserta DJJ pada Balai Diklat Keagaman Medan.

\section{Modul DJJ}

Untuk memproleh modul DJJ, dapat diperoleh melalui website Pusdiklat. Terkait modul tersebut untuk menambah pengetahuan peserta diklat, tutor mendownload modul terkait (link) ke beberapa website lain yang dapat diakses secara langsung atau di download oleh peserta DJJ. Modul yang digunakan untuk DJJ dalam bentuk CD. Modul yang dimiliki oleh penyelenggara tidak ada dalam bentuk cetak. Jumlah jenis modul yang harus dipelajari peserta untuk setiap angkatan dan jenis DJJ Sesuai desain kurikulum pelaksana DJJ. Proses memperoleh modul atau materi DJJ oleh peserta dibuat dalam bentuk CD atau mendownlode ke website. Jenis modul terdiri dari modul dasar, inti dan penunjang.

Antusiasme peserta terhadap modul cukup tinggi, yang dibuktikan dengan seringnya mereka mengakses modul dan mendiskusikannya dengan tutor. Bagi peserta yang kurang aktif akan segera diketahui, selanjutnya peserta tersebut akan mendapat teguran atau peringatan. Secara subtansi modul telah dapat menjawab harapan peserta atau dengan kata lain materi modul sudah cukup mendalam dan mudah dipelajari. Meskipun demikian, untuk lebih menarik modul diformat dalam bentuk format WEB adan E-book yang divariasikan dengan gambargambar atau animasi.

\section{Biaya Penyelenggaraan DJJ}

Biaya penyelenggaraan DJJ tahun 2010 berjumlah Rp 128.600.000,- untuk 2 (dua) angkatan, yaitu DJJ program studi Matematika dengan anggaran Rp 64.300.000,- dan DJJ program 
studi Bahasa Inggris dengan angaran Rp 64.300.000,-. Jumlah peserta untuk program studi Matematika 20 orang dan bidang studi Bahasa Inggris 20 orang. Alokasi biaya terbesar DJI adalah untuk komponen belanja perjalanan (524119) yaitu Rp 26.600.000,- (41.4\%) diikuti biaya honor yang terkait dengan output kegiatan (521213) yaitu Rp 14.750.000,- (22.9\%), biaya belanja bahan (521211) sebesar Rp 14.250.000,- (22.2\%), biaya belanja barang non operasional (521219) sebesar 6.000.000,(9.3\%), dan terakhir biaya belanja jasa profesi (522115) sebesar Rp 2.700.000,- (4.2\%).

Banyak sedikitnya biaya DJJ tidak bisa dibanding-bandingkan dengan biaya diklat lain, karena sesungguhnya DJJ adalah sebuah diklat alternatif yeng mempunyai kelebihan sekaligus kekurangan, dan ini tidak berbeda dengan diklat-diklat yang lain, sehingga biaya diklatpun harus diposisikan secara proporsional. Ketika lokasi peserta DJJ berasal dari daerah yang jauh-jauh dari Balai Diklat maka wajar bila biaya transfort jadi besar. Pembiayaan DJJ yang relatif rendah, maka tampak mempengaruhi dalam perekrutan peserta DJJ dimana DJJ di Balai Diklat Medan berasal dari daerah yang dekat dengan Balai Diklat itu sendiri.

\section{Proses Penyelenggaraan DJJ}

1. Metode Pembelajaran

Metode dan strategi tutor dalam proses belajar mengajar DJJ dilihat dari persamaan dan perbedaan dengan diklat biasa adalah: (a) peserta dapat konsultasi melalui fasilitas chating, email dan facebook, yahoo messenger; (b) waktu bebas, kapan peserta suka; (c) diklat biasa waktu sempit atau tertentu; (d) ruang gerak terbatas dalam kelas; (e) peserta terbatas 30 orang diklat biasa; dan (f) bila materi yang disampaikan melalui website bermasalah maka materi dikirim lewat email.

Model pembelajaran DJJ yang dikembangkan oleh Pusdiklat dan Balai Diklat Tenaga Teknis Keagamaan merupakan penggabungan antara pembelajaran berbasis modul tertulis dan Website (internet. Penggabungan model tersebut sering dinamakan dengan istilah blended. Pembelajaran DJJ Online dengan 
menggunakan media internet, TVE dan CD rekaman dari TVE . Sedangkan pembelajaran DJJ ofline menggunakan modul dari CD.

Dalam pembelajaran DJJ, tutor hanya menyediakan modul dalam bentuk website, yang selanjutnya ditentukan oleh keaktifan masing-masing peserta untuk mengakses internet kemudian dilanjutkan dengan dialog tanya jawab, diskusi, latihan dan akhirnya mengerjakan tugas, kuis maupun ujian mata diklat secara individual berdasarkan jadwal penyelesaian yang telah ditetapkan. Pada DJJ online, peserta dapat belajar kapan saja dan dimana saja melalui jaringan internet. Seluruh aktivitas belajar mencakup membaca atau mendownload bahan belajar, mengikuti forum diskusi, tutorial, chatting, mengerjakan tugas, latihan, ujian online dapat dilakukan melalui komputer yang terhubung dengan internet. Namun demikian keaktifan masing-masing peserta dalam mengakses internet sering terganggu terkait sinyal yang lemah.

\section{Penggunaan Tool dan Media}

Media DJJ yang dipergunkan adalah komputer atau notebook, jaringan internet, LCD, TVE, radio dan modul. Penggunaan fasilitas dan media dalam mendukung DJJ sudah baik, tapi berkaitan dengan akses internet masih kurang. Tempat belajar (off line atau online) DJJ meliputi tempat off line di BDK Medan dan tempat online di sekolah atau dirumah. Fasilitas yang dimiliki oleh tempat belajar DJj adalah internet, ruang belajar, multi media, modem dan Wifi, laptop dan komputer. Penggunaan tempat belajar DJJ (offline) sudah baik, tetapi berkaitan dengan akses internet masih kurang.

Pembelajaran DJJ menuntut peserta untuk belajar secara mandiri, aktif mengoperasikan website dan mengikuti perkembangan IT. Seluruh penyelesaian tugas, kuis dan ujian per mata dikat dilakukan melalui website dengan jadwal yang telah ditetapkan. Bagi peserta yang tidak dapat menyelesaikan tugas per-mata diklat berdasarkan jadwal yang telah ditetapkan akan tertinggal dan tidak dapat disusulkan. Begitu mata diklat baru dimulai maka mata diklat sebelumnya sudah dapat diakses kembali. Portofolio peserta dalam menyelesaikan seluruh tugastugasnya berpengaruh terhadap kelulusan program DJJ. Adapun 
tantangan penggunaan Media seperti: radio, TVE dan modul adalah ketika peserta mengalami kesulitan dalam memahami salah satu topik tertentu maka diperlukan adanya tutor sebagai nara sumber yang ada di sekitar tempat tinggal mereka. Berbeda dengan penggunaan tool, peserta harus memiliki ketrampilan dalam mengunakan IT, web, internet dan dapat mendiskusikan secara langsung dengan para tutor melalui chatting.

\section{Evaluasi DJJ}

Evaluasi DJJ mencakup evaluasi diklat dan mata diklat. Evaluasi diklat ditujukan untuk memberikan penilaian terhadap tingkat keberhasilan menyelesaikan program DJJ untuk menyatakan lulus atau tidak. Sedangkan evaluasi mata diklat ditujukan untuk mengukur hasil yang diperoleh peserta dan untuk mengetahui tingkat keberhasilan peserta dalam menyerap materi yang diberikan tutor. Aspek yang dinilai dalam evaluasi pembelajaran adalah tugas mandiri, tugas kelompok, tes tertulis, dan portofolio.

Evaluasi belajar mengajar DJJ dilakukan melaui pre-test, posttest, test on-line, test off-line. Adapun pelaksanaan pre test secara off line dan on line, dan post test juga dilakukan secara off line dan on line. Evaluasi mata diklat dilakukan melalui website (internet) dalam bentuk pertanyaan benar salah (true or false), pilihan ganda (multiple choice), masukan text (input text), pencocokan (maching-list). Evaluasi pembelajaran ini dilakukan oleh Tutor. Ada dua jenis evaluasi mata diklat yang dilakukan peserta yaitu tes mandiri dan ujian akhir. Tes mandiri dilakukan pada setiap akhir penyelesaian satu topik materi atau modul diklat. Sedangkan ujian akhir, dilakukan pada akhir program DJJ yang mencakup keseluruhan materi yang menggambarkan kompetensi yang ditetapkan.

Jadi di sini dapat dipahami bahwa evaluasi atau penilaian DJJ di Balai Diklat Keagamaan Medan diperoleh dari nilai total hasil pretest, keaktifan yang dapat dicermati dalam keaktifan online, hasil jawaban kuis, penyelesaian tugas-tugas yang diberikan, fortopolio melalui email, pembuatan makalah dan hasil posttest. 


\section{Durasi Pelaksanaan DJJ}

Durasi waktu pelaksanaan DJj setiap angkatan adalah 4 bulan (120 hari). Waktu yang efisien DJJ adalah 3 bulan. Apabila peserta mengakses $\pm 1,5$ jam sehari maka selama 3 bulan setara dengan 135 jam, adapun untuk pelaksanaan diklat regular membutuhkan waktu 100 jam. Jika DJJ dan Diklat regular durasinya akan disamakan mungkin DJJ cukup dilakukan 2 bulan saja.

Hal-hal yang perlu diperhatikan terkait dengan perubahan durasi DJJ adalah kebiasaan peserta dapat mengakses internet terkait DJJ selama 2 jam setiap hari, BDK perlu memperbesar bandwith website, dan bandwith di BDK juga harus mampu menampung \pm 40 orang lebih secara on line, dan selama ini baru menampung 5 orang. 17

Jam praktek DJJ untuk program Bahasa Inggis dilakukan pada siang hari tetapi waktunya masih bebas dan belum ditentukan. Adapun jam praktek DJJ untuk program studi Matematika dilakukan pada malam hari dan waktunya juga masih bebas dan belum ditentukan, sehingga ketika persoalan yang muncul itu banyak maka tutor merasa kewalahan. Untuk siaran TVE terasa belum memadai karena dari segi waktu belum ditentukan yang kadang dengan pemberitahuan yang mendadak jadi berbenturan dengan jam mengajar; di samping itu belum ada interaksi langsung dalam siaran TVE.

\section{Produk Penyelenggaraan DJJ}

\section{Frekuensi DJJ}

Komposisi peserta DJJ pada setiap wilayah diklat berdasarkan pada lokasi dan banyaknya jumlah GPAI yang diprioritaskan pada lokasi di luar kota Medan.Tahun 2010 dilaksanakan 2 DJJ untuk program studi Matematika dan Bahasa Inggris dengan jumlah peserta masing-masing 20 orang guru MTs. Pertimbangan tersebut diambil atas dasar banyaknya guru MTs untuk program studi Matematika dan Bahasa Inggris yang belum mengikuti diklat reguler. Dari masing-masing guru tersebut tidak ada yang

${ }^{17}$ Wawancara dengan tutor DJJ, Abdus Salam, Juni 2011. 
mengundurkan diri dari DJJ. Hampir seluruh peserta DJJ tahun 2010 dapat menyelesaikan hingga akhir diklat. Untuk DJJ program studi Bahasa Inggris dari 20 orang, 18 orang (90\%) dinyatakan lulus, dua orang yang tidak lulus karena yang satu sedang hamil tua tidak bisa mengikuti ujian dan yang satunya lagi karena tidak mengikuti ujian akhir DJJ. Adapun untuk DJJ program studi Matematika dari 20 orang 19 orang (95\%) dinyatakan lulus dan mendapat surat tanda lulus DJJ, sedangkan yang tidak lulus karena dia tidak mengikuti ujian akhir DJJ.

\section{Jangkauan DJJ}

DJJ di BDK Medan, menjangkau 5 kabupaten di Sumatera Utara, baik untuk DDJ program studi Bahasa Inggris maupun program studi matematika. Lima daerah tersebut adalah Kabupaten Deli Serdang, Kabupaten Binjey, Kabupaten Serdang Bedagai, Kabupaten Langkat, dan Kota Medan. Dari kelima daerah sasaran DJJ, semua daerah yang direkrut adalah yang dekat dengan kota Medan. Hal ini dilakukan karena beberapa pertimbangan, antara lain cost rendah, kavering area internet memadai, dan sarana IT banyak tersedia. Sesungguhnya DJJ adalah sebuah diklat alternatif yeng mempunyai kelebihan sekaligus kekurangan, dan ini tidak berbeda dengan diklat-diklat yang lain. DJJ bisa efektif semua aspek diposisikan secara proporsional, misalkan aspek biaya, banyak sedikitnya biaya tidak bisa dibanding-bandingkan dengan diklat lain, karena ketika lokasi peserta dari daerah yang jauh-jauh dari Balai Diklat maka biaya transfort jadi besar, dan dengan 3 pertemuan peserta DIJ di Balai Diklat yang selama ini dilakukan, itu jadi pemborosan, dan ada pendapat yang menyarankan cukup dilakukan satu pertemuan pada akhir DJJ saja dan ini penting terkait pelaksanaan ujian akhir atau post tes, sedangkan pre tes dapat dilakukan di daerah masing-masing bisa melalui online atau melalui pemberkasan pendaftaran di Kemenag terdekat. Pendapat lain mensarankan dilakukan 2 kali pertemuan peserta selama DJJ, dengan pertimbangan pada pertemuan pertama adalah kesempatan dilakukan pretest dan kegiatan orientasi atau pembekalan terkait penguasaan penggunaan internet. 
Dalam DJJ ditemukan beberapa orang peserta DJJ yang sebelumnya telah mengikuti diklat reguler dengan materi yang sama, mereka direkrut hanya karena pertimbangan penguasaan penggunaan internet. Hal ini perlu didudukan persoalannya, bahwa DJJ diselenggarakan atas pertimbangan untuk mempercepat siklus diklat dan diperuntukkan kepada mereka yang belum pernah mengikuti diklat terkait substansi tersebut. Rupanya DJJ di Medan masih salah paham dalam memahami perekrutan peserta DJJ yang mana mereka memahaminya yang belum pernah ikut DJJ. Terkait dengan pertimbangan penguasaan penggunaan internet sebenarnya dapat dilakukan kegiatan orientasi pada awal DJJ.

3. Respon Peserta DJJ

Penilaian peserta DJJ terhadap penyelenggaraan DJJ adalah berjalan dengan cukup baik. Program ini dirasakan sangat bermanfaat bagi peningkatan kompetensi guru. Peserta merasa antusias dalam mengikuti DJJ. Rata-rata mereka dapat menyelesaikan tugas, kuis dan ujian mata diklat sesuai dengan jadwal yang telah ditetapkan. Tanggapan mereka terhadap pembelajaran Online menjadi tantangan mereka untuk lebih banyak belajar IT. Sementara itu ada pandangan untuk modul dapat disajikan dengan model E-book atau model WEB sehingga lebih menarik untuk dipelajari. Pengaruh setelah mengikuti program DJJ juga sangat termotivasi untuk selalu belajar mandiri untuk mengembangkan kemampuan dirinya sebagai guru.

4. Nilai peserta DJJ

Nilai peserta DDJ pada akhir program untuk program studi Bahasa Inggris nilai rata-ratanya adalah 72.53 dengan kategori cukup baik, sedangkan untuk program studi Matematika nilai rataratanya adalah 81.42 dengan kategori baik. Ini menunjukkan penyelenggaraan DJJ telah berhasil dilaksanakan dengan baik yang diindikasikan bahwa hampir seluruh peserta DJJ tahun 2010 dapat menyelesaikan hingga akhir diklat. Untuk DJJ program studi Bahasa Inggris dari 20 orang, 18 orang (90\%) dinyatakan lulus. Adapun untuk DJJ program studi Matematika dari 20 orang 19 orang (95\%) dinyatakan lulus dan mendapat surat tanda lulus DJJ. 


\section{PENUTUP}

\section{A. Kesimpulan}

1. Dari segi konteks, DJJ dimaksudkan untuk mempercepat siklus diklat dan mengatasi keterbatasan jarak dan waktu antara penyelenggaraan diklat, tutor dengan peserta diklat, dengan memanfaatkan TIK. Pada awal DJJ belum dilakukan diklat pendahuluan bagi calon peserta DJJ terkait penguasaan IT/web/internet.

2. Dari segi input, ada beberapa komponen yang penting diperhatikan: (1) materi DJJ belum disesuaikan dengan kebutuhan riil masing-masing peserta DJJ; (2) modul belum diformat dalam bentuk web/E-book yang divariasikan dengan gambar-gambar atau animasi, (3) belum seluruh peserta DJJ menguasai dengan baik dalam menggunakan IT dalam mengoperasikan Website (internet); (4) tenaga admin adalah tenaga terlatih dan sebaiknya dari sarjana IT dan mampu berbahasa Inggris; (5) rekruitmen dapat dilakukan melalui data base dan memprioritaskan peserta yang jaraknya jauh dari BDK; (6) jumlah fasilitas IT masih terbatas; dan (7) alokasi biaya untuk tutor masih kurang terkait dengan beban pelayanan kepada peserta.

3. Dari segi proses, terdapat beberapa aspek yang penting diperhatikan: Model pembelajaran DIJ yang dikembangkan adalah blended, belajar mandiri melalui website sering terganggu terkait sinyal yang lemah, durasi DJJ bias lebih singkat dari 4 bulan menjadi 2 bulan bila kebiasaan peserta mengakses internet 2 jam perhari, bandwith di BDK masaih kecil sehingga daya tampungnya kurang besar secara On Line. Jam praktek DJI perhari belum ditentukan. Untuk siaran TVE terasa belum memadai karena dari segi waktu belum ditentukan dan belum ada interaksi langsung dalam siaran TVE.

4. Dari segi Produk, ada beberapa aspek yang penting dikemukakan yaitu: (1) dari lima daerah sasaran DJJ, masih terdapat peserta DJJ kota Medan, dan beberapa orang peserta DJJ yang sebelumnya telah mengikuti diklat reguler; (2) 
tanggapan peserta terhadap pembelajaran Online adalah mereka merasa tertantang untuk lebih banyak belajar IT; (3) untuk DJJ program studi Bahasa Inggris dari 20 orang, 18 orang $(90 \%)$ dinyatakan lulus, program studi Matematika dari 20 orang 19 orang ( $95 \%$ ) dinyatakan lulus dan mendapat surat tanda lulus DJj, adapun yang tidak lulus karena dia tidak mengikuti ujian.

\section{B. Rekomendasi}

1. Dari segi konteks, Pada awal DJj perlu dilakukan diklat pendahuluan|pembekalan bagi calon peserta DJJ terkait penguasaan IT/ web/internet.

2. Dari segi input, ada beberapa komponen yang penting diperhatikan: (1) materi DJJ perlu disesuaikan dengan kebutuhan riil masing-masing peserta DJJ; (2) modul perlu diformat dalam bentuk web/E-book yang divariasikan dengan gambar-gambar atau animasi, (3) peserta DJJ perlu menguasai dengan baik dalam menggunakan IT melalui kegiatan orientasi; (4) sebaiknya tenaga admin adalah tenaga terlatih dan dari sarjana IT; (5) sebaiknya rekruitmen dapat dilakukan melalui data base dan memprioritaskan peserta yang jaraknya jauh dari BDK; (6) perlu pertambahan jumlah fasilitas IT yang masih terbatas; dan (7) alokasi biaya untuk tutor perlu ditingkatkan agar pelayanan kepada peserta dapat maksimal.

3. Dari segi proses, terdapat beberapa aspek yang penting diperhatikan: (1) agar belajar mandiri tidak terganggu terkait sinyal perlu penambahan fasilitas yang memadai, (2) durasi DJJ bisa disederhanakan menjadi 2 bulan; (3) bandwith di BDK perlu diperbesar dengan daya tampung yang memadai secara On Line, (4) Jam praktek DJJ perhari perlu ditentukan, dan (5) Siaran TVE perlu ditentukan jam tayangnya dan perlu dibuat adanya interaksi langsung dalam siaran TVE.

4. Dari segi Produk, persoalan daerah sasaran DJJ sebaiknya mengutamakan daerah yang susah dijangkau, dan dari peserta DJJ yang belum mengikuti diklat reguler. 


\section{SUMBER BACAAN}

Arikunto, Suharsimi, dkk (2008): Evaluasi Program Pendidikan. Jakarta, Bumi Aksara.

Haryono, Anung, dan Abubakar Alatas (2003): Virtual Learning/ Virtual Classroom sebagai Model Pendidikan Jarak Jauh. Jakarta, JURNALTEKNODIK No.13/VII/TEKNODIK/DESEMBER/2003.

Ibrahim, Nurdin (2005): ICT Untuk Pendidikan Terbuka Jarak Jauh. Jakarta, JURNAL TEKNODIK No. 16/IX/TEKNODIK/JUNI/2005.

Kementerian Agama RI (2008): Buku Panduan Pengelolaan Diklat Jarak Jauh (DJ) bagi Admin BDK. Jakarta: Pusdiklat Tenaga Teknis Keagamaan.

Kementerian Agama RI (2008): Petunjuk Pelaksanaan Penyelenggaraan DJJ bagi Peserta DJJ, Pegawai Tenaga Teknis Keagamaan. Jakarta: Pusdiklat Tenaga Teknis Keagamaan.

Keputusan Menteri Agama (KMA) Nomor 3 Tahun 2006.

Negash, Solomon, et.al (2008): Handbook of Distance Learning for RealTime and Asynchronous Information Technology Education. New York: Information Science Reference.

Position Paper Kepala Badan Litbang dan Diklat Kementerian Agama pada Rakernas Balitbang dan Diklat di Banjarmasin tahun 2008.

Purwanto (2004): Pembelajaran Berbasis Teknologi Komunikasi dan Informasi Dalam Rangka Mewujudkan Keunggulan Proses Belajar. Jakarta, JURNAL TEKNODIK No.15/VIII/TEKNODIK/DES/2004.

Siahaan, Sudirman (2005): Pemanfaatan Teknologi dalam Penyelenggaraan Pendidikan terbuka/jarak jauh. Jakarta, JURNAL TEKNODIK No. 16/IX/TEKNODIK/JUNI/2005.

Tayibnapis, Farida Yusuf (2000): Evaluasi Program. Jakarta, Rineka Cipta.

Warsita, Bambang (2007): Peranan Teknologi Informasi dan Komunikasi dalam Penyelenggaraan Pendidikan Jarak Jauh. Jakarta, JURNAL TEKNODIK No. 20/XI/TEKNODIK/APRIL/2007. 